\title{
Dvě knihy o Olegu Susovi
}

Jiří Gabriel

V letech 2017 a 2018 připravil Ladislav Soldán (za přispění dalších Susových posluchačů) k vydání dvě publikace o filosofovi a estetikovi MU doc. PhDr. Olegu Susovi (1924-1982). První (z r. 2017) s titulem Oleg Sus méně známý (a stejně neúprosný) $)^{1}$ obsahuje výbor ze Susových textů mj. z rubrik Články, Recenze, Glosáře, Interviewy, Lektýrník a z jiných rubrik Hosta do domu 1968.

Čtenářům pamatujícím si na zmíněný rok není třeba sdělovat, že tento ročník Hosta do domu (HDD) nebyl zvolen náhodně. Z rubriky Články Soldán vybral texty „Generovaná degenerace“ (ukazující, k čemu může vést tzv. generativní gramatika s příslušným vybraným slovníkem), „Rozhovor s Golo Mannem“, z Interviewů „Vědecký interview Hosta s Romanem Jakobsonem“. V tomto rozhovoru se kladly a řešily zajímavé otázky z kulturní problematiky; např.: Jak se Vám podařilo „přivézt“ ruský formalismus a zasnoubit s ním českého ducha, aby vznikl český strukturalismus? Dala Vám hodně moudrost starých Čechů, a co by dnes mohla poskytnout světu moudrost nových Čechů? A je nějaká? Jak bychom si opatřili druhého Jakobsona?

Na články navazuje řada Susových recenzí. První dvě - „Velký univerzalista“ (o Březinových Esejich z pozůstalosti) a „Proklatě spílá koketnosti“ (o básnické sbírce

$1 \quad$ SUS, Oleg. Oleg Sus méně známý: (a stejně neúprosný) : z Článků, Recenzi, Glosárè, Lektýrníku, Sami proti sobě a jiných rubrik Hosta do domu 1968. Brno: Tribun EU 2017 (pozn. red.).
Josefa Jelena Pod sedmi pečetěmi) - jsou pro Suse netypické svým rozsahem (přes jednu stránku HDD). U Březiny chtěl zdůraznit jeho „duchovní typ, jenž je v naprostém sváru s banálním empirismem české střízlivosti, údajně pro nás typické“, u Jelena jeho rychlé „ometafořené a hochbanální překládání do poetočeštiny“. Na str. 13-56 se můžeme začíst do Susových pověstných recenzí v Hostu v rubrice 13 řádků ${ }^{2}$ Olega Suse. Šlo nejčastěji o recenze českých publikací básnických, beletristických, o jejích autorech, výjimečně sáhl po publikacích přeložených nebo odborných (např. Sešity novináre - Psychologie a sociologie hromadného sdélováni, Miroslav Heřman - Josef Dobrowský a české př́slownictvi). Více místa věnoval Sus recenzím v rubrice Glosár̆, o níž editor uvádí, že „pozornost mnoha čtenářů vzbudily rovněž kratší či delší zpravidla ostře píchavé články, podepsané nově vymyšlenými pseudonymy“; např. O jednom českém, zcela domácím antiběsu, Úplně tiši jako myšky, O galeriich na galejich českého jazyka, K teorii výstřelků, Člověk jako část prostoru. Tento svazek uzavřel editor medailonem o Susovi, bibliografií a obsáhlejším doslovem.

Druhý svazek Osmkrát Oleg Sus - vždy stejný a vždy trochu jiný3 připravil Ladislav Soldán s Bohumilem Marčákem. Obsahuje

2 Ano, skutečně šlo o recenzi na 13 řádcích, navíc poměrně krátkých (pozn. red.).

3 MARČÁK, Bohumil - SOLDÁN, Ladislav. Osmkrát Oleg Sus : Vždy stejný a vždy trochu jiný. Miroslav Klepáček - Sursum: Tišnov - Brno 2018. 
osm Susových portrétů (formátu 11,4cm x $8,5 \mathrm{~cm}$ ), které Bohumil Marčák pořídil původně pro revue Masarykovy univerzity Universitas. Dále v knize najdeme Susův „Vlastní životopis“ z roku 1963, napsaný pro děkanát Filozofické fakulty - jeho opis Soldán zařadil už do strojopisného sborníku In memoriam - Oleg Sus 1924-1982, jehož jediný exemplář převzala PhDr. Milada Susová. A také „Ještě jeden doslov..." Ladislava Soldána, doplňující obsah svazku o některá další sdělení, např. že ve 4. čísle Universitas 1995 byly Susovy fotografie „nikoli jen instruktivním doprovodem článku teoretika a historika výtvarného umění Jaroslava Sedláře“.

Čtenáře zaujmou rovněž krátké texty vztahující se k jednotlivým fotografiím, a tím k Susovi samému. Tak v textu k první fotografii čteme: „Většina těch, kteří na Olega
Suse po letech vzpomínají, tvrdí, že často připomínal zlého muže! Takto se často jevil nikoli jen básníkům a prozaikům, jejichž díla podrobil svým zcela neústupným kritikám, nýbrž i těm vysokoškolákům, jimž přednášel a které právě zkoušel. A je moc dobře, že mnozí z nich na takto rozezleného kritika nebo učitele nezapomněli - a bez jakéhokoliv předstírání vzpomínají na něj jen v dobrém; vždyt je právě něco nebo něčemu naučil!“ A u poslední fotografie: „Oleg Sus klidný; vůbec ne jenom uklidněný nějakou chimérou, přechodnou slávou (věru že polní trávou), a jistě ani ne vlastním životem. V této podobě jsem viděl svého učitele nejraději. A je dobře, že právě můj vyznavačský text o posledním snímku se stal nejkratším; k tomu ještě něco o brýlích: nedíváme se brýlemi, nýbrž očima." (Na fotografii má Sus jednu bočnici brýlí v ústech.)

\section{doc. PhDr. Jiří Gabriel, CSc.}

Brno, Česká republika

jgab@post.cz

Toto dílo Ize užít v souladu s licenčními podmínkami Creative Commons BY-NC-ND 4.0 International (https://creativecommons.org/licenses/by-nc-nd/4.0/legalcode). Uvedené se nevztahuje na díla či prvky (např. obrazovou či fotografickou dokumentaci), které jsou v díle užity na základě smluvní licence nebo výjimky či omezení př́slušných práv. 